\title{
Restoring the environment, revitalizing the culture: cenote conservation in Yucatan, Mexico
}

\author{
$\underline{\text { Yolanda Lopez-Maldonado }}^{1}$ and Fikret Berkes ${ }^{2}$
}

\begin{abstract}
Cenotes are sinkholes through which groundwater may be accessed from the Yucatan Peninsula Aquifer. Historically and culturally, cenotes are also important cultural and spiritual natural sites for the Maya, but they have been contaminated and degraded. We ask the following: What are the present-day meanings, understanding, and values of cenotes for the Maya? Is it possible to adopt a cultural approach for conservation of cenotes in Yucatan? Participant observation, interviews with stakeholders, and underwater exploration in cenotes were used to obtain data. Results indicate that cenotes often retain some spiritual meaning for people but not as important cultural, spiritual, or sacred sites. Little consensus was found regarding the significance of cenotes and how best to protect them. Informants noted changes in water quality, and identified the threats to cenotes including tourism, poor solid waste management, contamination, and deficiency of interest in preservation. Lack of accurate knowledge was a problem: informants did not seem to understand that cenotes are interconnected through the groundwater system. The Yucatan case illustrates how loss of cultural values can be linked to environmental quality and resource degradation. Conversely, it can be argued that cultural revitalization in indigenous communities has the potential to bring back community-based conservation.
\end{abstract}

Key Words: cenotes; community-based conservation; groundwater; Mayas; sacred natural sites; Yucatan

\section{INTRODUCTION}

Groundwater in Yucatan is not simply a hydrological resource. Historically it had elements of sacredness perhaps related to the fact that it was an essential resource in an area without rivers. It has since lost much of its sacredness and over the decades has become contaminated. In this paper we deal with groundwaterrelated issues in Yucatan, and suggest that the way to improve conservation is through the inclusion of cultural values and renewed spiritual connections between people and their environment. Understanding cultural values, belief systems, and meanings are often necessary toward solutions; looking at nature with awe and reverence fosters sensitivity to the environment (Wild and Macleod 2008).

The notion of cultural connection to nature is mediated through sacred natural sites in various parts of the world. Sacred sites are areas of land or water having special spiritual significance to peoples and communities, and may include mountains, hills, forests, groves, rivers, lakes, lagoons, islands, springs, and caves (Oviedo and Jeanrenaud 2007, Thorley and Gunn 2008, Wild and McLeod 2008). They are the oldest protected areas of the planet, constitute biodiversity hotspots, and are useful for conservation (Dudley et al. 2009, Metcalfe et al. 2010). However, sacred natural sites are subject to a diversity of threats, including culture change, which can lead to loss of spiritual values. Protecting sacred sites is especially critical in indigenous communities, since these places constitute unique social-ecological landscapes, a source of cultural identity (Oviedo and Jeanrenaud 2007, Samakov and Berkes 2016).

In dealing with the erosion of natural and cultural values in Yucatan and their possible restoration, we adopt the concept of community-based conservation, that is, resource management or biodiversity protection by, for, and with local communities, recognizing the coexistence of people and nature, as distinct from protectionism, and the exclusion of people from nature (Western and Wright 1994). The most appropriate theory for the analysis of community-based conservation is commons theory, whereby conservation at the local-level, under local institutions, may be seen as one part of a multilevel commons problem (Cash et al. 2006). Yucatan groundwater, as a commons, is a resource important at multiple levels from local to international (Berkes 2007). It fits the Ostrom et al. (1999:278) definition of a commons or common-pool resource: those "in which (i) exclusion of beneficiaries through physical and institutional means is especially costly, and (ii) exploitation by one user reduces resource availability for others." The Yucatan groundwater issue can be considered a collective action problem: a group of people, such as a community or society, would benefit from a certain action, but no individual has sufficient incentive to act alone (Ostrom 1990).

Yucatan has a large aquifer that is shared by local communities. In our exploration, community-based conservation in the Yucatan case requires a biocultural approach that considers both biophysical and social-cultural aspects of conservation (Maffi and Woodley 2010, Gavin et al. 2015). Community-based conservation has received increasing attention in recent years, partly because of the recognition that conservation efforts should address human needs, and that such efforts should not rely only on the government (Borrini-Feyerabend et al. 2004, Berkes and Turner 2006). The groundwater case in Yucatan illustrates the complexity of the problem, and how a biocultural approach can be used to support water resources, biodiversity, and local values, and foster environmental restoration and cultural revitalization.

The inclusion of spiritual enrichment, cognitive development, reflection, recreation, and aesthetic experiences helps the protection of sacred natural sites (Wild and McLeod 2008). Both cultural and spiritual values of ecosystems relate to the importance of indigenous worldviews, knowledge, and traditions often manifested in the form of respect and tribute to local 
wisdom (Verschuuren and Furuta 2016). Environmental problems cannot be solved by rational arguments alone, they also require emotional engagement (Anderson 1996). Hence, indigenous knowledge and traditional worldviews may help to preserve sacred natural sites through the emotional involvement of people with their environment.

In Yucatan, most groundwater research has focused on its hydrology and environmental problems (Hernández-Terrones et al. 2011, Polanco-Rodríguez et al. 2015). This is of importance since successful monitoring and management often calls for a clear understanding of the groundwater system. For example, Lopez-Maldonado et al. (2017), found that high wastewater emissions are discharged to the aquifer without treatment. Wastewater range from grey water to wastewater with high concentrations of organic matter, i.e., discharges from pig farms, and alkaline discharges, i.e., tortilla industry; all wastewater emissions are discharged directly to the aquifer without any treatment; despite rapid recharge of rainwater circulating in the system, this water is not collected for further use, and poor recycling practices $(<1 \%$, relative to the total water emissions). The results also illustrate disparity among sectors, and conflicts among the main extractors and polluters. However, we contend that there is another aspect of this issue: the relevance of local cultural values. The integration of local values and revitalization of sacred natural sites can lead to better groundwater management.

Yucatan is an area of places of cultural and environmental significance, most of them water-related, including traditional sacred natural sites such as human-made monuments, springs, landscapes, and caves (Healy 2007). The land of the Yucatec Maya, one of the largest groups of indigenous peoples in Mexico, has permeable limestone formation (karst), which results in precipitation quickly seeping into the groundwater. There are no surface rivers in Yucatan, but only groundwater in the form of a large, extensive aquifer that underlies most of the State of Yucatan plus parts of two adjoining states. Rain enters the karstic platform and percolates quickly down through the porous limestone to form underground channels. The aquifer in Yucatan is reachable from the surface through thousands of sinkholes, locally called cenotes (from the Mayan word ts'onot; Huntington 1912) and aguadas. In Yucatan, aguadas are not as well defined as the cenotes. Some are artificial and some are natural. The natural ones can be permanent or exist during the rainy season. The artificial ones were apparently built by the Maya to conserve water during the dry season. Most of the aguadas are shallow compared to the cenotes. Aguadas were a common water resource in the southern Maya Lowlands where they originated from collapse or dissolution of cenotes (Akpinar-Ferrand et al. 2011).

Cenotes are all types of karst features including caves and springs, can vary in size from the very small to interconnected cave systems, and can be found on land and inshore marine areas. In principle all cenotes in Yucatan are connected; however, it is possible that, because of sedimentation, some ducts were filled and cenotes become isolated (E. Batllori-Sampedro, Ministry of Environment Yucatan, personal communication, 7 December 2016). In some cenotes nature itself can be sacred, while in others sacredness can be conferred by connections with ancestral spirits, human-made structures, or sacred histories (Brady et al. 1997). The Maya have a particular cosmology and worldview, which gives shape to current cultural values. For the Maya, cenotes were sacred sites and one of the most important elements for the survival during the dry season (Scarborough 1998, Medina-Elizalde and Rohling 2012, Turner and Sabloff 2012).

Thus, the groundwater system was (and still is) a critical commonpool resource (Ostrom 1990) with multiple values, shared by communities over a large area. Cenotes, as accessible water points from the aquifer, played a major role in religion, politics, and subsistence, provided fish, clay for pottery, and stalactites to build altars, and were associated with rituals and ceremonies displaying water symbolism (Dunning et al. 1997). They were thus set aside as religious sites, as places inhabited by spirits (MacLeod and Puleston 1978, Lucero 1999, Lucero et al. 2011). Cenotes needed to be culturally protected and evidence of this can be found throughout the entire Mayan zone. In some places, they continued to be protected even after the Spanish Conquest.

For Yucatan's present population of nearly two million (INEGI 2012), groundwater is the only major source of freshwater. However, even though local people possess values and some knowledge about water, they continue to have a heavy impact on the resource including wastewater discharges and poor solidwaste disposal practices. Problems include water resource scarcity and pollution due to development, biodiversity loss, and resource degradation (Hernández-Terrones et al. 2011, Metcalfe et al. 2011, Lopez-Maldonado et al. 2017; Fig. 1).

Fig. 1. Cenotes in Yucatan suffer from poor solid waste disposal practices (before and after cenote clean-ups in the fieldwork phase) Photos: Y. Lopez-Maldonado.

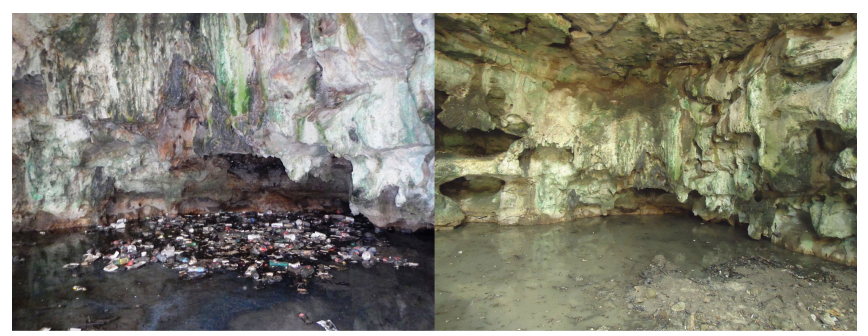

Despite progress on hydrological and environmental studies, cultural values and social aspects of cenotes are not well documented. As a way of approaching groundwater conservation, we explore how local meanings can support protection. We seek further understanding of current values that communities themselves consider as important. The Yucatan case serves to elucidate a conservation approach that considers present-day meanings and local community values. Concepts including sacred natural sites (used here in the wider nonreligious sense), and revitalization of cultural traditions are used to define communitybased conservation of sacred natural sites as the act of maintaining, safeguarding, and sheltering environmentally and culturally important places by integrating conservation and local cultural values that give meaning to the local people. The aim is to recognize the cultural and spiritual aspect of nature in the local context, even if those values may not be recognized by the whole community. 
Focusing on a selected area in Yucatan, the paper deals with two interrelated research questions: What are the present-day meanings, understandings, and values of cenotes for the Maya people? What are the prospects of adopting a biocultural approach for community-based conservation of cenotes in Yucatan?

\section{METHODS}

\section{Study area}

\section{Ecological context}

Three Mexican states, Yucatan, Campeche, and Quintana Roo, are found in the area of the Yucatan Peninsula Aquifer. The aquifer comprises thirteen hydrogeological units, four of these are located in Yucatan, including the Ring of Cenotes, a unique water system formed by a meteor impact 65 million years ago (Hildebrand et al. 1991). The Ring has been recognized as a Ramsar site, and tentatively included in the list of the UNESCO World Heritage sites (SEDUMA 2014). Our case study was the Geohydrological Reserve zone located within the Ring in Yucatan (Fig. 2). The Ring encompasses a Natural Protected Area, the Yalahau Lagoon. Several groundwater caves, or cenotes, account for the majority of karst groundwater flow. The cenotes are mostly used for human consumption and their distribution is usually controlled by rainwater recharge, extractive uses (water for irrigation, farms, and fields, hotels, industries), and discharges into the sea. The study area contains diverse habitats and vegetation zones, and cenotes and aguadas that are part of a Geohydrological Reserve (Pacheco-Avila et al. 2014), a priority area for environmental protection established in 2014 with the aim to secure the provision of water for the metropolitan region.

Fig. 2. Map showing the Geohydrological Reserve zone in Yucatan, Mexico, and the cenotes explored (precise locations are not given).

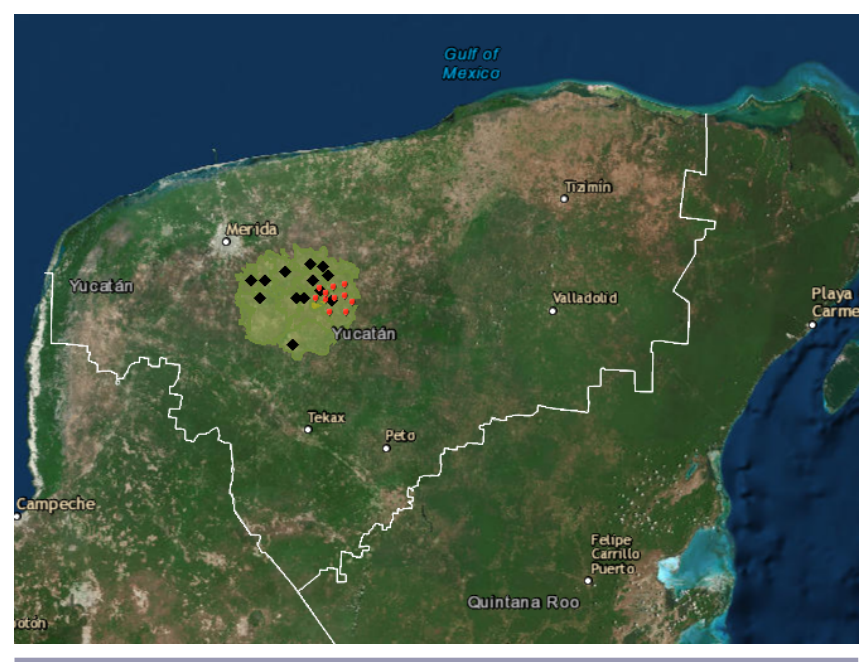

Cultural context

In the Reserve there are 13 municipalities. All of them are in the recharge zone of the Ring of Cenotes, within which is located the city of Merida and its metropolitan zone. The area has the majority of cenotes in Yucatan State, and important historical and cultural characteristics that come from the time of the ancient Mayas. The Mayan communities that developed in this region were closely related to the use of the cenotes as a source of fresh water; that is why archaeological and cultural sites can be found associated to the majority of these cenotes.

There is past and present archaeological evidence of the importance of sacredness of cenotes in the Mayan area (Brady et al. 1997, Prufer and Dunham 2009). The importance of the water to the Maya is simple: everything seems to be related to water and the underworld, where supernatural beings live, where the souls of the dead go, and where ancestors reside (Bonnafoux 2011). Historically, practices and culture were water-rainfall oriented (Lucero 1999, Lucero et al. 2011). Archaeological sites with such evidence provide signal of long-term spiritual connection and cultural importance. Recently, a cenote was found under the main structure of El Castillo in Chichen Itza, one of the greatest Maya centers of Yucatan, (UNAM 2015; Fig. 3). This suggests that the cenotes in the Mayan area were culturally valued and respected in the past.

Fig. 3. Photo of "El Castillo" in Chichen Itza, one of the greatest Maya centers of Yucatan. The arrow indicates the approximate location below the pyramid where the cenote was found. Photo: Y. Lopez-Maldonado.

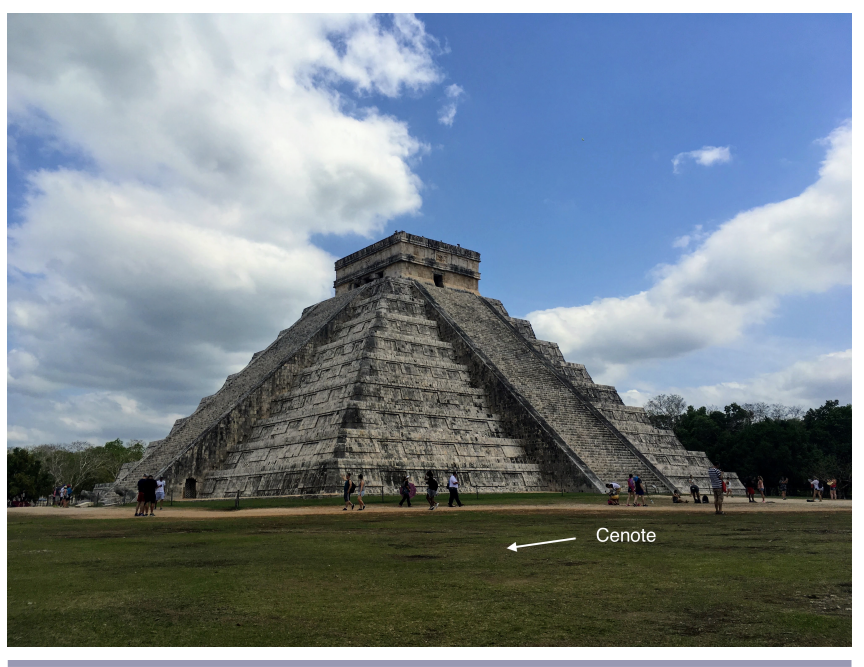

Political context

Despite the economic importance of cenotes, there is no particular law that regulates its management in Mexico's federal legislation. The National Water Commission (CONAGUA) links the federal, state, and municipal governments for the exploitation of national waters by providing concessions and permits for groundwater extraction to public or private persons. However, in terms of management, municipalities are independent because they only receive technical advice from the local water supply company (JAPAY) (L. Caceres, Department of Culture for Water National Water Commission, personal communication, 29 December 2014). Most rural households own pozos (wells), meaning that water can be extracted from all local wells without a proper concession. This creates conflicts among users related to issues of ownership or problems with boundaries, extraction, and pollution. 
It is estimated that there are between $400-450$ cenotes in the study area and they are interconnected (J. Ruiz, Department of Karst, Ministry of Environment Yucatan, personal communication, 12 December 2014) out of an estimated 2000 cenotes and caves in Yucatan State. The total is uncertain because some of them have been recorded under different names, and multiple entrances to one site have often been recorded as separate sites. The Ring is perhaps the best-surveyed zone, but a full inventory is not available. Efforts began in 1996 to establish a standardized data collection bridging biological, archaeological, and land use aspects (SEDUMA 2014). The Ring contains mostly hydrological information, despite the fact that cenotes hold ancestral values as well.

The Maya depended exhaustively on groundwater resources for the provision of water. Thus, they had to design, build, and control their own water sources since ancient times (Huntington 1912, Scarborough and Gallopin 1991, Dunning et al. 1997, Scarborough 1998). Sacred places were related and shaped by water rituals, including those connected to the Dios Chaac (Water God; Veni 1990, Scarborough 1998). This implies detailed resource knowledge and a belief system that reflects the intimate relationship between water and people. However, none of the existing literature explicitly integrates that knowledge and present-day values or practices associated with cenotes in a clear way. To do this properly, we think that papers that include indigenous scholars as coauthors are especially important (Johnson et al. 2016). We speculate that through participatory action, linking indigenous and local knowledge with modern scientific and technical approaches, and revitalization of values can provide support to monitor, interpret, and care for groundwater ecosystems.

\section{Study methodology}

Primary data were collected through a triangulation of four methods: (a) participant observation, (b) open-ended interviews, (c) discussions with stakeholders and authorities, and (d) underwater exploration of cenotes, in addition to hydrological findings reported elsewhere. Secondary data were also used, including exhaustive review of karst inventories and official reports from the Ministry of Environment of Yucatan (SEDUMA 2014). More than 400 reports were analyzed to determine cultural elements and human-made karst modifications. We used literature sources for background, along with ethnographic descriptions of the communities. The large dataset made it possible to develop an interview guide and to test our questions.

Overall, fieldwork and interviews were developed during different stages from 2014 to 2017 , over a period of 10 months. We applied the snowball technique to interview local people in the communities. We developed workshops with representatives of the water sector and with members of the Communitarian Spaces for Water Management (ECAs) in Yucatan. The ECAs are part of a Federal program established by CONAGUA in 2002 with the aim to promote and strengthen community participation in water related issues and to promote good uses of the resource among the population. In Yucatan, during the fieldwork phase there were 79 ECAs in 80 municipalities (considering that more than two ECAs can be found in urban centers and large communities).
Participants from various agencies and sectors were interviewed, including members and experts of the water sector (e.g., the National Water Commission, the water supply company), socioeconomic sectors (e.g., members of the maize industry, representatives of the livestock sector), experts from local institutions (e.g., members of the Technical Committee for the Study of the Groundwater System in Yucatan), and local members. Interviews of 21 experts working in different sectors provided representative data to examine local opinions of this group. The interviews also included local people from the communities in the study area and around the perimeter of the reserve, allowing comparisons on groundwater and cenote issues to be made between those living near Merida and those living in rural areas. One community in the state of Campeche was also included to provide an example of how opinions in that region differed from opinions in Yucatan. In relation to the total sample of 109 participants, we ensured that the sample was regionally representative.

We carried out two workshops, one with a group of experts and one with members of the ECAs. For the interview process, a group of experts was selected (Technical Committee for the Study of the Groundwater System in Yucatan), based on their previous experience of groundwater and cenote issues. ECA members were convened by invitation with the support of the Ministry of Health. We implemented informal conversations and interviews with the participants. The objectives were to investigate how people ascribed meaning to cenotes in Yucatan and to explore possible solutions about how cultural and spiritual values could be recognized for better groundwater management. Interviews included general socio-demographic questions about participants such as gender and age, and one specific section related to the significance of cenotes. Interviews were developed based on the findings during the revision of the SEDUMA reports. The interview stage was followed by informal conversations that were valuable because they allowed for a robust understanding of how cenotes are perceived by participants.

Overall, the project focused only on communities that had not been previously explored by SEDUMA (2014). Twelve cenotes in the Reserve, including caves, were explored in November and December 2014. The communities were selected based on their geographic location (located in the perimeter of the Reserve). We visited some families, which have cenotes in their gardens, and carried out informal conversations for information about how they took care of their cenotes. Overall, all the cenotes were registered, mapped, and video-recorded; speleological drawings, which included formations, biodiversity, and ancient cultural material, were made with the support of local divers. The precise locations of the sites explored are not given. There had been few archaeological cave surveys and projects in the area, including the studies performed in the SEDUMA database. Using the SEDUMA survey of cenotes in the area as baseline, cenotes were explored and the results obtained complemented SEDUMA reports including videos, photos, interviews, drawings, and reference books and papers than can be used for further research in the area.

A case study approach was used (Yin 2009). We explored the communities, carried out participant observation in two of them, and conducted interviews $(\mathrm{N}=109)$ with 69 local Maya people, 
Fig. 4. Example of information obtained to create the index cards used to explore cenotes.

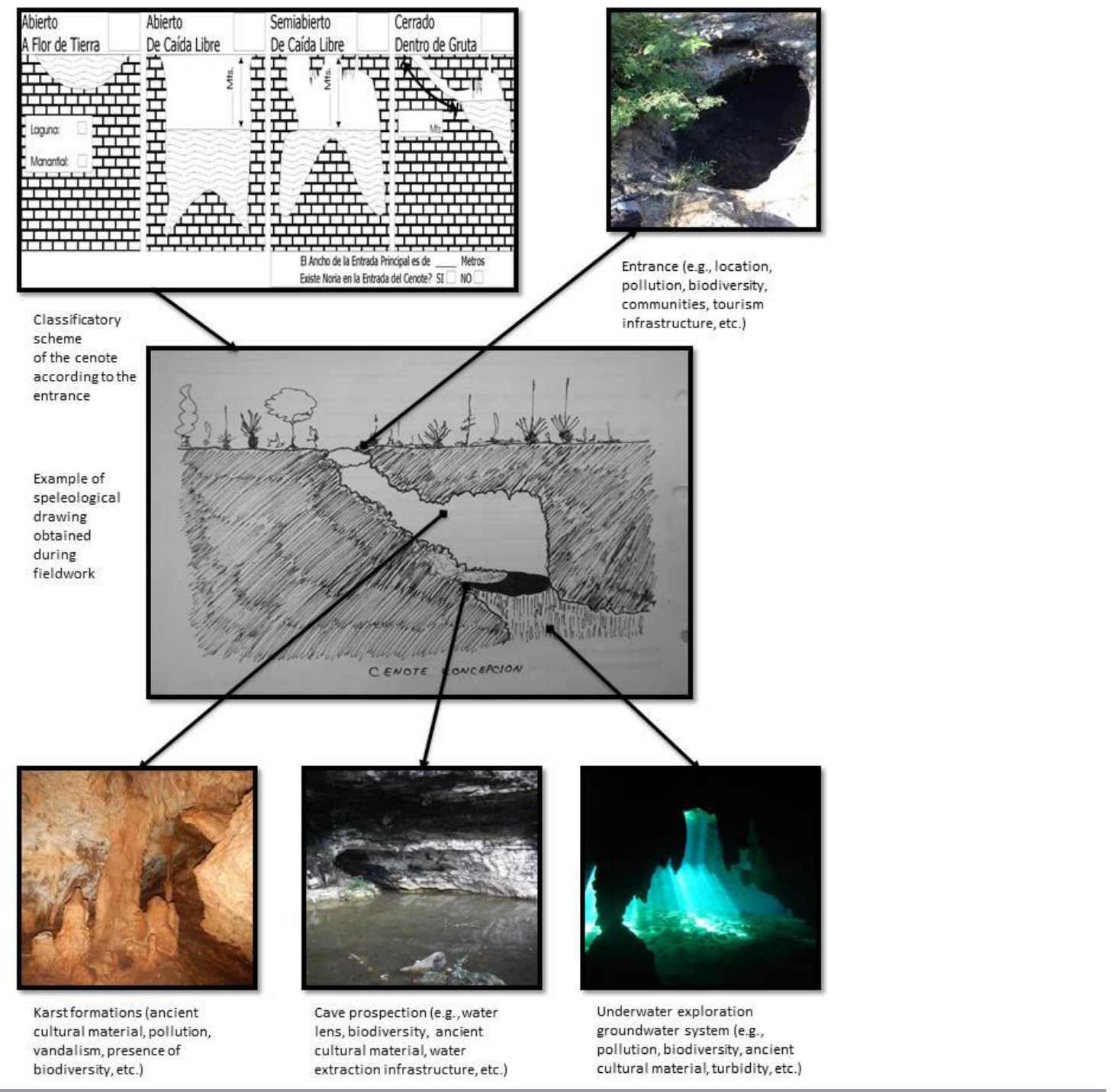

21 academics, 3 government officials, 1 tourism operator, 2 cave divers, and 13 others working in different water related sectors (Table 1). These were complemented by informal conversations with a wider range of people. We used our previous knowledge of the area and people, and snowball technique to identify community leaders and representative participants. We asked about current knowledge of cenotes near the community, because in most cases local people did not know exactly where the cenotes were located but did know that they existed. We held meetings with underwater explorers to get information from a speleological point of view, and asked for photos or cave material that informants considered as illustrations of sacredness. In the communities we began by asking local members about Mayan words they used to describe water quality and if they considered some cenotes sacred or not. The transcripts of interviews were analyzed for themes that occurred frequently. We include here some quotes recorded during fieldwork. A detailed list of the organizations represented can be found in Table 2.
Table 1. Age and gender details of informants.

\begin{tabular}{lcccc}
\hline \hline & $<25$ years old & $25-60$ years old & $>60$ years old & All \\
\hline Women & 26 & 20 & 5 & 51 \\
Men & 27 & 22 & 9 & 58 \\
Total & 53 & 42 & 14 & 109 \\
\hline
\end{tabular}

Speleological records obtained during cave explorations provide information about architectural formations and possible past uses such as rituals or ceremonies. Geomorphological characteristics, hydrological factors, presence of biodiversity, and cultural traces, as well as pollutants were noted. For the speleological prospection, vertical and horizontal progression techniques were applied (Cuenca Rodríguez et al. 2010). Cenotes were classified in relation to current use, visible pollution, presence of cultural material, and governance regime using an index card system (Fig. 4). 
Table 2. Organizations represented in the interviews, and their roles and responsibilities, in the analysis of the cenotes in Yucatan.

\begin{tabular}{|c|c|c|}
\hline Organization & Responsibilities & Participants \\
\hline Ajau (NGO) & User association & 1 \\
\hline Autonomous University of Yucatan & Research on Hydrology and Hydraulics & 3 \\
\hline Cámara de la Industria del Vestido de Yucatán & User association & 1 \\
\hline $\begin{array}{l}\text { Center for Research and Advanced Studies Mexico } \\
\text { (Dept. of Human Ecology and Dept. of Applied } \\
\text { Physics) }\end{array}$ & Research and coordination & 2 \\
\hline $\begin{array}{l}\text { Center of Scientific Research of Yucatan (Water Science } \\
\text { Unit) }\end{array}$ & Research and coordination & 1 \\
\hline $\begin{array}{l}\text { CIR-UADY (Health, Environment and Development } \\
\text { Unit) }\end{array}$ & Research & 1 \\
\hline Colectivo Na' Lu' Um (NGO) & User association & 3 \\
\hline CONAGUA & Environmental Authority & 2 \\
\hline CONANP (Natural Protected Areas) & Environmental Authority, coordination & 1 \\
\hline $\begin{array}{l}\text { Consultores en Agua Potable, Alcantarillado, } \\
\text { Geohidrología \& Hidráulica Costera, I.C. }\end{array}$ & Consultancy & 1 \\
\hline Technical Committee for the Study of the Groundwater & Implementation, planning, research, and management for the & 10 \\
\hline System in Yucatan & $\begin{array}{l}\text { Yucatan aquifer, support to river basin organization of the Yucatan } \\
\text { Peninsula }\end{array}$ & \\
\hline ECAs (Communitarian Spaces for water culture $)^{\dagger}$ & $\begin{array}{l}\text { Community members who promote and strengthen participation in } \\
\text { water related issues and good uses of the resource }\end{array}$ & 68 \\
\hline Ecologistas Subacuaticos (NGO) & Environmental activism (community activities, cenote clean-ups) & 2 \\
\hline Indigenous Development Center & Implementation & 1 \\
\hline Local Livestock Association of Pig Farmers of Merida & User association & 1 \\
\hline Local water supply company & $\begin{array}{l}\text { Service provider, coordination of the local sewage system, support } \\
\text { for local communities in water issues }\end{array}$ & 1 \\
\hline Maize industry sector & User association & 1 \\
\hline Ministry of Environment in Yucatan & Environmental Authority & 2 \\
\hline Ministry of Health & Environmental Authority & 2 \\
\hline Municipality representatives & Coordination, implementation, planning & 4 \\
\hline Organismo de Cuenca Península de Yucatán & Coordination, implementation, planning & 1 \\
\hline
\end{tabular}

\section{RESULTS}

Results are grouped under three major headings: (i) present-day uses of cenotes in the area, (ii) contemporary meanings and values of cenotes for the local population, and (iii) changes in values for recognition of cenotes as sacred natural sites, an indication of the potential for community-based conservation in the area.

\section{Present-day uses of cenotes}

One way to understand how the Maya people appropriate and value nature is through an analysis of how they ascribe meaning to it. Although it is possible to find cenotes all over Yucatan, past research efforts concentrated on a few places close to archaeological zones. We documented unrecorded cenotes, including some caves and aguadas, and carried out clean-up and other activities with the young (Fig. 5). Given the significance of cenotes in the past, it might be anticipated that indigenous people would emphasize social and cultural values. Nevertheless, as can be seen in Table 3, sacredness of cenotes did not come up in the list of current uses, implying that utilitarian values are at the forefront. Participants gave priority to functional values of cenotes mainly as a source for water used in cattle ranching, agriculture, and tourism. Table 3 also includes notes on visible pollution, presence or absence of ancient cultural material from underwater exploration, governance regime according to interviews, and biodiversity values from SEDUMA reports.
Fig. 5. Example of some of the activities performed during the project, (a) cenote clean-ups with community members, (b) workshops with members of the ECA, and (c) speleological and (d) underwater exploration (Photos: Lopez, Y.).
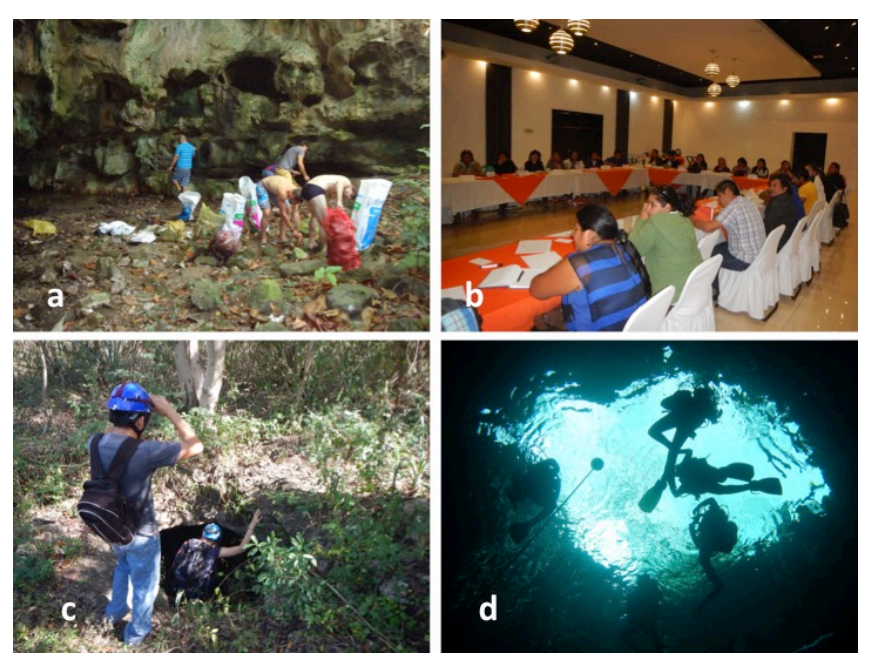

Given that some protected areas have been established (Yalahau Lagoon and the Reserve) in the study area, one might expect to find joint management and conservation-compatible human 
Table 3. Characteristics and common uses of cenotes explored in the Geohydrological Reserve Zone.

\begin{tabular}{|c|c|c|c|c|c|c|c|}
\hline No. & Name $^{\dagger}$ & Current use & $\begin{array}{l}\text { Level of } \\
\text { Pollution }\end{array}$ & $\begin{array}{l}\text { Cultural } \\
\text { material }\end{array}$ & Governance Regime ${ }^{*}$ & $\begin{array}{l}\text { Biodiversity (common and scientific } \\
\text { name) }\end{array}$ & $\begin{array}{l}\text { Comments and } \\
\text { remarks } \S\end{array}$ \\
\hline 1 & La Noria & Cattle farming & High & Yes & $\begin{array}{l}\text { Ejido } \\
\text { Open access State } \\
\text { property }\end{array}$ & $\begin{array}{l}\text { Bagre (Rhamdia guatemalensis) } \\
\text { Langostino (Creaseria morleyi) } \\
\text { Ramon (Brosimum alicastrum) } \\
\text { Huano (Sabal Mexicana) }\end{array}$ & $\begin{array}{l}\text { Future plans for } \\
\text { ecotourism }\end{array}$ \\
\hline 2 & Huhi & Not in use & High & No & $\begin{array}{l}\text { State property } \\
\text { Open access }\end{array}$ & & Open dumpsite \\
\hline 3 & Concepcion & Agriculture & High & No & $\begin{array}{l}\text { Ejido } \\
\text { Open access }\end{array}$ & Bagre (Rhamdia guatemalensis) & $\begin{array}{l}\text { Clandestine open } \\
\text { dump site }\end{array}$ \\
\hline 4 & Papaya & Not in use & Low & Yes & $\begin{array}{l}\text { Open access, State } \\
\text { property } \\
\text { Not specified }\end{array}$ & $\begin{array}{l}\text { Bagre (Rhamdia guatemalensis) } \\
\text { Waxim (Leucaena leucocephala) }\end{array}$ & $\begin{array}{l}\text { Clandestine open } \\
\text { dumpsite }\end{array}$ \\
\hline 5 & La Peinada & Not in use & Low & Yes & $\begin{array}{l}\text { Ejido } \\
\text { Open access State } \\
\text { property }\end{array}$ & $\begin{array}{l}\text { Langostino (Creaseria morleyi) Henequen } \\
\text { (Agave fourcroydes) }\end{array}$ & $\begin{array}{l}\text { Future plans for } \\
\text { ecotourism }\end{array}$ \\
\hline 6 & Uxutún & $\begin{array}{l}\text { Cattle farming, } \\
\text { apiculture }\end{array}$ & High & Yes & $\begin{array}{l}\text { Ejido Private } \\
\text { property }\end{array}$ & $\begin{array}{l}\text { Tilapia (Oreochromis mossambicus) } \\
\text { Bagre (Rhamdia guatemalensis) }\end{array}$ & $\begin{array}{l}\text { Future plans for } \\
\text { ecotourism } \\
\text { Pesticide bottles } \\
\text { found }\end{array}$ \\
\hline 7 & Saktún & Apiculture & Low & Yes & $\begin{array}{l}\text { Ejido } \\
\text { Private property }\end{array}$ & $\begin{array}{l}\text { Langostino (Creaseria morleyi) } \\
\text { Bagre (Rhamdia guatemalensis) } \\
\text { Serpiente coral falsa (Sibon sartorii) } \\
\text { Chaya (Cnidoscolus chayamansa) } \\
\text { Piñuela (Bromelia pinguin) }\end{array}$ & $\begin{array}{l}\text { Future plans for } \\
\text { ecotourism }\end{array}$ \\
\hline 8 & Mudzuy & $\begin{array}{l}\text { Agriculture } \\
\text { Cattle farming } \\
\text { Human } \\
\text { consumption }\end{array}$ & High & Yes & $\begin{array}{l}\text { Ejido } \\
\text { Private property }\end{array}$ & $\begin{array}{l}\text { Bagre (Rhamdia guatemalensis) } \\
\text { Mojarra (Cichlasoma urophtalmus) } \\
\text { Tilapia (Oreochromis mossambicus) }\end{array}$ & $\begin{array}{l}\text { Pesticide bottles } \\
\text { and a gallon } \\
\text { containing diesel } \\
\text { found, gasoline } \\
\text { spill }\end{array}$ \\
\hline 9 & Torcaza & Agriculture & High & Yes & $\begin{array}{l}\text { Ejido } \\
\text { Private property }\end{array}$ & $\begin{array}{l}\text { Ceiba (Ceiba speciosa (L.) Gaertn) } \\
\text { Ramon (Brosimum alicastrum) }\end{array}$ & $\begin{array}{l}\text { Herbicide bottles } \\
\text { found } \\
\text { Recommended for } \\
\text { ecotourism }\end{array}$ \\
\hline 10 & $\begin{array}{l}\text { Tixcacal } \\
\text { Quintero }\end{array}$ & $\begin{array}{l}\text { Agriculture } \\
\text { Cattle farming }\end{array}$ & Medium & No & $\begin{array}{l}\text { Ejido } \\
\text { State property }\end{array}$ & $\begin{array}{l}\text { Langostino (Creaseria morleyi) } \\
\text { Chaya (Cnidoscolus chayamansa) }\end{array}$ & $\begin{array}{l}\text { Recommended for } \\
\text { ecotourism }\end{array}$ \\
\hline 11 & No name & $\begin{array}{l}\text { Agriculture } \\
\text { Cattle farming }\end{array}$ & High & Yes & $\begin{array}{l}\text { Ejido } \\
\text { Private property } \\
\text { Open access }\end{array}$ & Langostino (Creaseria morleyi) & $\begin{array}{l}\text { Recommended for } \\
\text { ecotourism }\end{array}$ \\
\hline 12 & Xtohil & $\begin{array}{l}\text { Agriculture } \\
\text { Cattle farming }\end{array}$ & Low & Yes & $\begin{array}{l}\text { Ejido } \\
\text { Open access }\end{array}$ & $\begin{array}{l}\text { Langostino (Creaseria morleyi) } \\
\text { Pich (Enterolobium cyclocarpum) }\end{array}$ & $\begin{array}{l}\text { Construction of a } \\
\text { main road will } \\
\text { close the entrance } \\
\text { of the cenote }\end{array}$ \\
\hline
\end{tabular}

$\dagger$ The name of the communities and precise location of the cenotes are not included to protect the cultural material found.

* According to the responses obtained during the interviews with stakeholders.

${ }^{\S}$ As reported in the SEDUMA database and responses obtained during the interviews with authorities and stakeholders.

activities. However, the presence of reserves does not seem to have motivated sustainable resource use and cultural practices. For example, protected areas were not identified well by any of the interviewees, and neither were archaeological zones associated with cenotes. There was no consensus regarding current management and what else can be done to protect them. The alarming decline in water quality was frequently mentioned. Fifty-two participants reported that, prior to the mid-1990s, they could drink water directly from the pozos (wells), but presently they did not because they could become sick. One interviewee said the following:

In the past 25-30 years, we used to drink water from our pozo [...]. Nowadays water is not drinkable and that is the reason why we prefer to buy bottled water. (Informal conversation, farmer, male, 50 years old).
We collected information on governance. Because cenotes and the Yucatan groundwater basin are commons, we classified governance according to the terms used in the commons literature (Ostrom 1990): (1) state property: when the cenote is owned by government authorities; some responsibilities may be shared with the community; (2) private property: when an individual owns a cenote on their private land; (3) collective property or ejido: when the cenote is owned by ejido members; and (4) open-access: when the cenote does not have well-defined property rights and is open to everyone and all uses. Ejidos are common-use lands and lands intended for housing and urban infrastructure. They are different from communal land by being an endowment granted by the government to an organized group of farmers with no land (Jones and Ward 1998, Torres-Mazuera 2009). 
It appears that the contemporary governance status of cenotes includes all four of these regimes but is mostly mixed or unclear (Table 3). What used to be communal property, under communal care, in ancient times has become mostly unmanaged state property verging on open-access. In effect, cenotes have been decommonized (Lopez-Maldonado 2015) into open-access, suffering from degradation, the usual consequence of open-access (Ostrom 1990). Community respondents did not seem to associate contamination of cenotes and the governance regime, and what that might imply for stewardship responsibilities. Cenotes used for tourism activities are managed according to environmental regulations, but there is a lack of regulation for other cenotes. One member of a tourism cooperative observed the following:

We are six members in this cooperative. The land and cenote does not belong to us, the Ejido members donated all. We can use the cenote and the land for the next 30 years and then we need to move or to extend the agreement. We can do wherever we want, but we need to follow government rules. For example, we cannot use pesticides around the cenote and we cannot modify the entrance of the cave, nor add lamps [...]. (Interview, member of tourism cooperative, female, 56 years old).

The role that local people could play in the management of cenotes came up for discussion during informal conversation with experts working on the water sector but mainly regarding contamination. For example, the Reserve was so designated because of the quality of water. However, some cenotes in the Reserve have been reportedly contaminated with pesticides (Polanco-Rodríguez et al. 2015). Toxic contamination was not reflected in the understanding of participants regarding water quality, and pesticides were not mentioned as a potential factor affecting groundwater, even though in five of the cenotes explored, pesticide bottles were found. Chemical pollution challenges some of the responses indicating that water clarity was the essential criterion for considering a cenote as sacred or not, and suggests that water in cenotes has lost much of its former sacredness. One interviewee said the following:

We used to live here in the ranch and we did not have another [source of] water to drink. We had to drink water from the cenote. We never got sick because water was sacred and it was always clean. (Interview, Municipal authority, male, 43 years old).

Respondents were asked how they characterized the water in the Mayan language, because linguistics often provides insights into local perceptions; the way in which a resource is named and categorized helps to understand their knowledge system. Responses were diverse and confusing: concepts such as clean, transparent, turbid, stinky, or with sacred powers such as pure water were mentioned. Interviewees used over 20 different terms for water (Table 4). However, they were not able to express a particular idea for agua contaminada or agua sucia (Spanish for contaminated or polluted water). Participants recognized the presence of virgin water or Sujuy $J a^{\prime}$ in some cenotes but they did not mention the use of this water for healing or as sacred water. Nine out of 25 used the term $J a^{\prime}$ when referring to clean water in a cenote, but indicated that this water was not suitable for human consumption. Twelve out of 109 mentioned the term Eek $J a^{\prime}$ as water that is not suitable for drinking, but they did not connect this concept to contamination (Table 4). These mixed results are consistent with the regional database in which more than $50 \%$ of the cenotes were registered as contaminated (SEDUMA 2014). Interestingly, more than the half of the group of experts $(\mathrm{N}=21)$ were not able to define any of the Maya terms.

Table 4. Selected terms and ideas expressed regarding the concept of water.

\begin{tabular}{|c|c|c|}
\hline Maya & English & Spanish \\
\hline$J a^{\prime}$ & Drinkable water & Agua para beber \\
\hline Luuk' & Mud & Fango, lodo \\
\hline Boombil Ja' & $\begin{array}{l}\text { Water containing } \\
\text { substances (e.g., } \\
\text { gasoline) }\end{array}$ & Agua con substancias \\
\hline Boox $\mathrm{Ja}^{\prime}$ & Black water & Agua negra \\
\hline Ch'a ch'alkil Ja' & Oily water & Agua aceitosa \\
\hline Ch'e'en Ja' & Water from a well & Agua de pozo \\
\hline Ch'ooch' Ja & Salty water & Agua salada \\
\hline Ch'ujuk Ja' & Fresh water & Agua dulce \\
\hline Chaltun $J a^{\prime}$ & $\begin{array}{l}\text { Limestone/calcareous } \\
\text { water }\end{array}$ & Agua de laja ${ }^{\dagger}$ \\
\hline Chokoj Ja' & Warm water & Agua caliente, tibia \\
\hline Eek $J a^{\prime}$ & Turbid/blurry water & Agua turbia \\
\hline Eek $^{\prime} J a^{\prime}$ & Black water & Agua negra \\
\hline K'ook'ol & Impure water & Agua impura \\
\hline Ki'irits Ja' & Dingy water & Agua cubierta de polvo \\
\hline Óomil Ja & Foamy water & Agua espumosa \\
\hline Tóos lu'umbil Ja' & Dusty water & Agua con polvo \\
\hline$T u^{\prime} J a$ & Stinky water & Agua hedionda \\
\hline Saasil Ja' & Clean water & Agua limpia \\
\hline Siis Ja' & Cold water & Agua fria \\
\hline Sujuy Ja' & Virgin/pure water & Agua virgen, pura \\
\hline 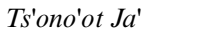 & Water from a cenote & Agua de cenote \\
\hline Ya'as $J a^{\prime}$ & Greenish water & Agua verdosa, verde \\
\hline Yoom Ja' & Scummy water & Agua espumosa \\
\hline
\end{tabular}

${ }^{\dagger}$ Laja in Yucatan is a common, natural limestone found underneath the soil $(0.3$ to $2.5 \mathrm{~cm})$.

${ }^{\star}$ Impure water refers to water with additional innocuous compounds. However, in the Mayan native vocabulary it refers to water that has lost its main healing properties.

${ }^{\S}$ Indigenous people recognized the Spanish concept for contaminated water (agua contaminada) but they did not have a native Mayan word for it.

Participants were perceptive to contamination because they explained that quality of groundwater was not suitable for human consumption in some cenotes, but not in all of them. Responses indicated that interviewees did not understand that all cenotes are part of a single interconnected groundwater system and cultural values do not seem to be considered.

\section{Contemporary meanings and values}

Evidence of ancient sacredness of groundwater in the Yucatan Peninsula is everywhere. Many of the cenotes explored contained ancient Maya pottery, fire pits, human and animal remains below the water table. Furthermore, the SEDUMA database contains references to ceremonies and some cave systems being considered as sacred routes. Sacredness appears to be understood by some, but certainly not all, of the respondents. Indigenous respondents perceived cenotes as the abode of deities and spirits, and that cenotes were primarily used for rituals in the past. 
In the past, cenotes were sacred but not all of them now. There are some of them that can serve to [carry out] ceremonies such as the Cha-Chaac (ceremony for the God Chaac) but they are few and it is not easy to reach them [the cenotes]. (Interview, beekeeper, male, 50 years old).

We interviewed participants about the current importance of cenotes. We used the example of one cenote in Yucatan (the Sacred Cenote of the archaeological zone in Chichen Itza) to exemplify the concept of sacred. We asked if they can tell why the cenote Sagrado in Chichen Itza is called "Sacred", and what the Mayas from the past used to do with the water of that cenote. Did they think that cenotes we have today are the same cenotes the Mayas used in the past? We asked the participants to explain and expand on each response. We then asked if they think sacred cenotes still existed in Yucatan. Questions about supernatural agencies in local people's beliefs were also explored. We asked about Aluxes (name given to a spirit in the mythological Maya tradition). Most participants, including experts, seemed to have some belief in the Aluxes. One respondent mentioned: "The Sacred cenote in Chichen Itza is sacred because it was important for the Mayan ceremonies [...]. The water was used to support the needs of the population. The other cenotes in Yucatan are the same cenotes as those in the past because they require a lot of time to form. However, present cenotes are contaminated" (Interview, housewife, female, 35 years).

Interestingly, 89 respondents rejected the idea that cenotes continue to represent sacred places but they did mention that they believed in the importance of the cenote in Chichen Itza and in Aluxes as protectors and caretakers of the cenotes. This suggests that the link between sacredness and cenotes has been broken, even for some who acknowledged spiritual powers:

I don't know the cenotes and I've never been into a cave but I know that there exists some spirit that inhabits there and protects the entrance of the cenote. (Informal conversation, student, male, 20 years old).

According to some respondents, loss of respect for cenotes may be related to the erosion of sacredness across generations. Knowledge of cenotes as sacred natural sites was no longer being transmitted to younger generations. One diver member of a local NGO working on the protection of cenotes noted the following:

The problem is the lack of education among the younger people, between 15 to 24 years old. As explorers of caves and cenotes, we always find beer bottles, spirit bottles, condoms, graffiti, etc. I do not believe that older people visit cenotes and do all of these things. Besides, it is difficult to access some of these sites and not everyone has the skills to descend [into the cenotes]. The young people have to be involved more in the tasks of protection and conservation. (Informal conversation, cave diver, male, 24 years old).

We recorded information on current management, legends, and (where possible) rituals or ceremonies. Some of the legends were consistent with the idea that all cenotes once had names and spiritual guardians or "owners." Some interviewees seemed to know of the ancient institution of cenote guardians, spiritually powerful humans or animals. Twenty-four interviewees mentioned that the guardian of the cenote is a snake. None of the respondents themselves were guardians. One interviewee said "In order to be a guardian you have to have knowledge and special powers as X'menes (Mayan healer) used to have. No one has it now, it is something that someone was born with."

In interviews and participant observation in the one community in Campeche State, we found that the population still practiced some water-oriented ceremonies (see Video). We interviewed local members and found a profound sense of respect for cenotes. However, we also found high density of pesticide bottles in the area and evidence of high levels of solid waste (mainly plastics) contamination, suggesting lack of knowledge of their impact on the groundwater system and the consequent environmental effects.

Overall, cenotes were assessed according to specific characteristics including accessibility and safety. Some cenotes were considered unsafe places by about half of the respondents. Seventy-eight of the interviewees reported being afraid of entering into a cenote, and almost all the participants $(\mathrm{N}=101)$ said they would only visit them for recreation. People believed cenotes were dangerous places because of vandalism, drug and alcohol use, hazardous species that inhabit dark places, e.g., spiders and snakes, or because underwater streams can cause drowning.

\section{Changes in values regarding cenotes as sacred natural sites}

Values, beliefs, and meanings regarding cenotes sacredness seem to have declined. Although some ancient Maya indigenous beliefs still exist, cenotes have been suffering from an erosion of values, including the way people perceive nature and environmental change implications. Indicators of these changes in values were evident during the interviews. One woman reported having a pozo, which she considered far more important to her than a cenote:

We have pozos in our houses. All here in the village have their own pozo, therefore why are we going to take care of cenotes if what we use comes from the pozo. I better take care of my pozo because I take water from it. (Interview, ECA member, female, 43 years old).

Value and environmental change also impacted biodiversity and habitats of endemic species, including blindfish (Typhliasina pearsei, sak-ay in Mayan) and the blind swamp eel (Ophisternon infernale). Participants mentioned that the impact on biodiversity in cenotes was due to the introduction of species such as tilapia (Oreochromis mossambicus), water extraction, demolition of cenotes and natural areas to construct tourist facilities and roads, direct human consumption of cenote water, abandonment of ceremonies associated with sacred beliefs, wastewater discharges, and solid waste disposal.

Results from interviews and informal conversations indicated a failure of knowledge transmission of cenotes as sacred sites. More than the half of the respondents $(\mathrm{N}=62)$ expressed a strong desire to learn about cenotes, to restore cultural practices, and to revitalize values of sacred places. Overall, interviews and informal conversations revealed a profound sense of loss of local and traditional knowledge of uses and practices, e.g., rainwater harvesting, and a lack of self-recognition as custodians. According to the testimony of many elders who have witnessed 
tremendous change over the past years, responses indicated the loss of meaning and value among the local population. Interviewees identified threats to the cenotes, lack of interest in preservation, and changes in water quality. But little consensus was found regarding the significance of cenotes, how to better protect them, and what trade-offs may be involved.

Cenotes have become a major tourist attraction, posing threats such as loss of respect. The designation of the Geohydrological Reserve, meant as a conservation measure, has had the impact of increasing tourism, compounding problems through modifications of cenotes, for example, to improve tourist access. Paradoxically, those cenotes are less contaminated with plastics and better preserved because the local population is interested in tourism income.

\section{DISCUSSION: A BIOCULTURAL APPROACH TO CENOTE CONSERVATION}

Current conservation strategies in Yucatan do not include cultural values in groundwater and biodiversity conservation efforts. Likewise, current government policies do not mesh well with cultural values and the possibilities of cultural revitalization; thus, there is a lack of biocultural appreciation (Maffi and Woodley 2010). However, the Ring of Cenotes (and the Reserve) is on the tentative list of the UNESCO World Heritage Site, providing international recognition of the biocultural significance of the area. Findings of ancient cultural material such as pottery, figures, animal and human bones during our fieldwork are consistent with previous results of archaeological research in Yucatan State (Andrews 1981), as in entire Mesoamerica (Healy 2007, Prufer and Dunham 2009). Even though communities may no longer hold, or even know about, their traditional belief systems, they seem to be interested in protecting these sites. However, without an appreciation of traditional cultural and spiritual practices, as well as current practices, it would be difficult to understand how contemporary conservation can foster transformative change toward environmental stewardship.

Cenotes are linked to individual and community well-being, but their values have been eroded and sacredness, as a motivator, lost. As well, communal values have been largely replaced by individual values. The quotations about wells makes this clear (why worry about "cenotes if what we use comes from the pozo"). Communities will benefit from conservation action, but no individual seems to have sufficient incentive to act alone. Using commons theory terminology, there is a collective action problem (Ostrom 1990, Nyborg et al. 2016). However, there may be ways to motivate local communities by involving their knowledge, beliefs, and values to enable community-based conservation, which in turn benefits communities and society as a whole, addressing the collective action problem.

What are the prospects for using community-based conservation strategies to protect cenotes and thus Yucatan's groundwater resources? Elements of such an approach may include the following. First, there is a need for cultural revitalization to restore spiritual connection of people to cenotes. Second, the consideration of the integrated social-ecological system through a biocultural approach needs to replace government's conventional sectoral, expert-based, regulation-driven conservation. Third, the governance of cenotes has to be revised by restoring community ownership and communal responsibility for cenotes where feasible through devolution of government authority. Fourth, an ongoing educational campaign at all levels, but especially aimed at school children and youth, is needed to transmit knowledge and values about cenotes. We expand on each of these points.

First, cultural revitalization is necessary because it supplies the emotional engagement to conserve (Anderson 1996). Cultural revitalization can go hand in hand with ecosystem restoration, as seen in some indigenous areas in the United States, such as the Nisqually Tribe of Washington State (Grossman 2010) and elsewhere (Maffi and Woodley 2010). However, cultural revitalization is not an easy process; it has to start from the bottom-up. Through disempowerment and dispossession brought about by colonization, it has become difficult for indigenous peoples to relate to their environment. In many areas however, indigenous peoples search for personal and spiritual meaning. As reservoirs of meaning and identity, sacred natural sites can represent important ways for establishing relations with the environment (Oviedo and Jeanrenaud 2007, Wild and McLeod 2008). For example, Huicholes of northern Mexico continue to live their everyday and ceremonial lives according to ancestral practical knowledge. They perform ancient ceremonies and rituals in the desert region called Wirikuta, where their ancestors reside and manifest themselves as rocks, mountains, animals, or plants (Myerhoff 1974, Neurath 2003). Their local and traditional knowledge frame the way in which they interact with nature.

Cenotes are seriously contaminated (Metcalfe et al. 2011, Polanco-Rodríguez et al. 2015), but our results indicate that the local people perceive contamination in a different way from scientific understanding. The linguistic classification of water (Table 4) reflects local knowledge, and the terms for different perceptions of "water" are helpful to deepen the analysis of how to improve water management to go from an undesirable to a desirable state. For example, cenotes were considered as sources of "virgin water" in the past, and there is archaeological evidence for this belief (Andrews 1981, Prufer and Dunham 2009). However, contemporary people have noticed a distinct deterioration in the quality of water and say that it is very difficult to find sources of virgin water. Instead, there is a rich terminology for bad water instead of drinkable $J a^{\prime}$. Cultural revitalization, in the form of people reclaiming ownership of their culture and recognizing the value of virgin and drinkable water, can provide the impetus for reversing the degradation trend. Restoring and revitalizing the present-day meanings of cenotes and good water can help reconnect ancient and present Maya wisdom, along with a better understanding of water contamination.

Second, we need to recognize different values of conservation and ask, what kind of conservation? People in Yucatan believe in protecting cenotes for cultural and spiritual reasons, conservationists seek to protect groundwater ecosystems and biodiversity, and government authorities want to protect the aquifer. However, these interests do not seem to overlap as they should, as if we were dealing with three separate conservation objectives. Bringing these objectives together requires a biocultural approach (Gavin et al. 2015). Our findings indicate that authorities do not recognize the potential of sacred sites for biodiversity conservation, and that local knowledge is not used alongside scientific knowledge. 
To operationalize a biocultural approach, cenotes must be understood as integrated social-ecological systems from the indigenous perspective, including current values and local knowledge (Samakov and Berkes 2016). Local and indigenous knowledge should be integrated into hydrological management plans and be recognized at the policy level. Further studies on cultural values regarding cenotes are needed for fuller documentation and better understanding. Sacred natural sites located in protected areas should be integrated into the planning processes. Similarly, cultural values could be integrated into tourism planning to safeguard against excessive loss of spiritual characteristics due to commercialization and commodification of cenotes.

Third, these considerations raise the question of governance. Inconsistent water governance regimes, laws, and policies, as well as local practices, pose huge problems for cenote conservation. In general, management strategies for groundwater or cenotes do not include indigenous peoples in the decision-making process. However, the biocultural approach to conserve biodiversity and cultural diversity together highlight the need to include local voices in decision making. Current governance of cenotes is complex because some of them are under state management, others under the control of communities, and some of them are private. Most of them are under mixed regimes or simply openaccess. In 10 out of the 12 cenotes explored, there was still some ejido governance (Table 3 ) and this signals an opportunity for community-based conservation and local stewardship. However, this also might indicate a potential for confrontations and problems with cenote water use and land use rights (OswaldSpring and Sanchez-Cohen 2011).

Conservation of cenotes can be considered as a commons problem, specifically as a multilevel commons problem (Berkes 2007) because each cenote is part of the larger hydrological system. It is not possible to consider each cenote as an isolated resource: water extraction or pollution of each cenote has repercussions for all (or nearly all) other cenotes, aguadas, pozos, and the groundwater system as a whole. Multilevel commons require a matching multilevel governance system (Berkes 2007). Community-based conservation represents grassroots interests, and the control of cenotes by communities provides local incentives to protect them.

Taking the long view, community-based conservation, if it could be instituted, reverses the historic trend of decommonization whereby cenotes had been turned into open-access over the colonization period (Lopez-Maldonado 2015). Communitybased conservation would restore cenotes as locally controlled commons, a commonization process (Nayak and Berkes 2011). Restoration of local control can be a support tool for cultural revitalization and help stimulate local values of sacred sites. Community-based conservation is not in conflict with state conservation; it is complementary. The combination of different levels of management allows for governance pluralism and social justice in the restoration and use of the resource.

Cenotes on private lands or those controlled by tourism interests have been effectively privatized. But they are still part of a hydrological system and require oversight by public institutions at municipal, state, and national levels. Managing and protecting cenotes from a holistic perspective, as commons, probably requires the cooperation of a whole network of public and private actors: communities, governments, industry associations, private owners, NGOs, and educational institutions. Typically in a multilevel commons situation, these actors may be connected with vertical and horizontal linkages, in which vertical links connect across levels (e.g., municipal - state - national) and horizontal links connect within levels, such as a cluster of communities that communicate and learn from one another (Berkes 2007).

Fourth, education is a necessary component of a successful biocultural conservation program, specifically to supplement the weak intergenerational transmission of cultural values of cenotes. Education is needed at all levels and sectors: the youth, local people, government officials, industry representatives and educational institutions themselves. As a primary objective, cenotes can be used for educational purposes at various levels for preserving local knowledge, and making sacred sites a core for community conserved areas. Integrating cultural and natural values of past and present Maya culture into a focal point can help establish a benchmark for cultural identity, whereby expressions of culture, including ceremonies, dances, and songs can be preserved.

Hence, cenotes can be used to highlight indigenous Maya knowledge and to legitimize the importance of sacred values. As known from elsewhere (Verschuuren and Furuta 2016), ancient sites often retain at least a residual spiritual meaning for people, even if original belief systems have been much eroded. Conservation may build on such values, and the elaboration of these indigenous values can be used to educate the larger society (Zurba and Berkes 2014). Cenotes are being promoted for tourism development, and communities are interested in tourism income. However, none of the interviewees raised the possibility of using cenote tourism to educate society. Protection is more pertinent if the spiritual aspect of the site is considered as significant in itself, a useful lesson for the dominant society. This can be a call to protected area managers, landowners, government authorities, locals, and other stakeholders to recognize the importance and legitimacy of sacred values embedded in cenotes.

Likewise, there are specific educational targets for community people and others. Lopez-Maldonado et al. (2017) found that, even though groundwater is currently the main source of freshwater for the population, crucial information about the state of the system, e.g., precise location, function, quality, quantity, etc., is limited and poorly understood. For example, the meaning of polluted water and an interconnected groundwater system was not apparent in the language or the imagery of the interviewees. What they did describe was more like an idealized, historical single cenote as a continuous aquatic "clean" underworld without considering that cenotes are interconnected. This lack of groundwater system understanding was persistent in all of the interviews, and seemed to influence the way in which water quality was perceived. There can be no clearer sources of information regarding the importance and sacredness of cenotes than the importance of recognizing and revitalizing ancient Maya wisdom to help protect groundwater and the society that depends on it. Thus, Lopez-Maldonado et al. (2017) emphasized the importance of groundwater literacy: the knowledge of the users about the resource and its attributes, and the perception and valuation of impacts on the system. 


\section{CONCLUSIONS}

Cenotes are sinkholes through which people access water from the Yucatan Peninsula Aquifer. Because cenotes are interconnected, they cannot be managed as isolated entities. Similarly, cenotes are part of a millennial culture and cannot be managed in isolation from that culture. Even though culture and environment are no longer closely coupled in current Yucatec Maya society, cenotes cannot be managed and understood without recognizing the values and knowledge of local communities. Thus, there is a need for revitalization and recognition of cenotes as sacred natural sites. Communities are the most appropriate actors to initiate collective action, with support from a network of other stakeholders, to reverse threats and encourage stewardship in younger generations.

Commons theory does not explicitly recognize the revitalization of indigenous cultures and social norms as essential for commons management. However, the present case shows that groundwater conservation in Yucatan cannot come solely from government regulation and privatization. It may be best initiated by the revitalization of community values and norms, in this case, the recognition of cenotes as sacred sites. The social enforcement of respect for cenotes and groundwater restores individual incentives to act in ways that benefit communities and society. Hence, restoring cultural values is the way communities can foster conservation and solve the collective action problem (Nyborg et al. 2016). Through such collective action, individuals themselves, as well as the community, can derive social and economic benefits from conservation, consistent with commons theory (Berkes 2004).

The revitalization of spiritual values needs to be supported by at least three other community-based conservation strategies, as detailed in the previous section: (a) the adoption of a biocultural approach to replace government's conventional sectoral or discipline- and expert-based, regulation-driven conservation; (b) governance reform to restore community ownership and communal responsibility for cenotes through devolution of government authority; and (c) an ongoing educational campaign at all levels to transmit knowledge and values about cenotes.

Strengthening of community culture and knowledge is important also for maintaining the ecological integrity of cenotes because sites need to be conserved as reservoirs of biodiversity. This is one potential area of cooperation between local and scientific knowledge (Wild and McLeod 2008). Traditional ecological knowledge or indigenous knowledge is a source of biological information and ecological insights for conservation (Berkes 2012). However, until recently, inclusion of indigenous knowledge into planning was not even considered. Conservation of protected areas should be designed to work with local people (BorriniFeyerabend et al. 2004). Moreover, if social and ecological systems are going to be approached as integrated complex systems, there is need to develop a model of conservation that takes into account the complexity of Maya society and the complexity of the groundwater system, and the relationships between the two as a social-ecological system (Berkes 2004). Naturally there is always cultural change and loss of some values, changing the ways in which groundwater is used. But these values can also change still further, toward conservation. Such changes would necessarily involve deliberation and mutual learning among the people engaged (Berkes and Turner 2006).
The main driving forces behind the growing interest in the protection of cenotes are human activities, development, and environmental impacts. There is potential for the recognition of the importance of cultural values in Yucatan groundwater conservation. Internationally, efforts have been made and methods and approaches developed to assess the cultural values of indigenous communities regarding their ecosystems (Oviedo and Jeanrenaud 2007). However, the present study makes clear the need for the inclusion of indigenous thinkers, policy makers, and local people in the understanding of those values, traditions, and beliefs.

\section{Responses to this article can be read online at: http://www.ecologyandsociety.org/issues/responses. php/9648}

\section{Acknowledgments:}

We thank the stakeholders and the communities that voluntarily were involved in this research. Many thanks to facilities and information provided by the Ministry of Environment in Yucatan (SEDUMA) and to Abel N. Tun for revision of Maya translation. We also thank to J. Ayuso for his helpful comments. Funding from Consejo Nacional de Ciencia y Tecnología (Scholarship 312243) and Canada Research Chairs are acknowledged.

\section{LITERATURE CITED}

Akpinar-Ferrand, E., N. P. Dunning, D. L. Lentz, and J. G. Jones. 2011. Uuse of aguadas as water management sources in two southern Maya lowland sites. Ancient Mesoamerica 23:85-101. http://dx.doi.org/10.1017/S0956536112000065

Anderson, E. 1996. Ecologies of the heart. Emotion, belief and the environment. Oxford University Press, New York, New York, USA.

Andrews, A. 1981. El "Guerrero" de Loltun: Comentario analitico. Boletin E.C.A.U.D. Y. 48:36-50.

Berkes, F. 2004. Rethinking community-based conservation. Conservation Biology 18:621-630. http://dx.doi.org/10.1111/ j.1523-1739.2004.00077.X

Berkes, F. 2007. Community-based conservation in a globalized world. Proceedings of the National Academy of Sciences of the United States of America 104:15188-15193. http://dx.doi. org/10.1073/pnas.0702098104

Berkes, F. 2012. Sacred ecology. Third edition. Routledge, New York, New York, USA.

Berkes, F., and N. J. Turner. 2006. Knowledge, learning and the evolution of conservation practice for social-ecological system resilience. Human Ecology 34:479-494. http://dx.doi.org/10.1007/ s10745-006-9008-2

Bonnafoux, P. 2011. Waters, droughts, and early Classic Maya worldviews. Pages 31-48 in C. Isendahl and B. Liljefors Persson, editors. Ecology, power, and religion in Maya landscapes. Acta Mesoamericana Vol. 23. Verlag Anton Saurwein, Malmö, Sweden. 
Borrini-Feyerabend, G., A. Kothari, and G. Oviedo. 2004. Indigenous and local communities and protected areas: towards equity and enhanced conservation. Guidance on policy and practice for co-managed protected areas and community conserved areas. IUCN, Gland, Switzerland.

Brady, J. E., A. Scott, A. Cobb, I. Rodas, J. Fogarty, and M. Urquizú Sánchez. 1997. Glimpses of the dark side of the Petexbatun Project. The Petexbatun Regional Cave Survey. Ancient Mesoamerica 8:353-364. http://dx.doi.org/10.1017/ $\underline{\mathrm{S} 0956536100001784}$

Cash, D. W., W. N. Adger, F. Berkes, P. Garden, L. Lebel, P. Olsson, L. Pritchard, and O. Young. 2006. Scale and cross-scale dynamics: governance and information in a multilevel world. Ecology and Society 11(2):8. http://dx.doi.org/10.5751/ES-01759-110208

Cuenca Rodríguez, J., J. C. Fernández-Cainzos, M. J. GonzálezRíos, J. Larios-Gómez, M. López Molina, J. L. Membrado Julián, E. Ogando Lastra, S. Palacios Pérez, F. Ramírez Trillo, and A. Tellez Gottardi. 2010. Técnica y formación en Espeleología. 1a Ed. Federación Española de Espeleología, Madrid, Spain.

Dudley, N., L. Higgins-Zogib, and S. Mansourian. 2009. The links between protected areas, faiths, and sacred natural sites. Conservation Biology 23:568-577. http://dx.doi.org/10.1111/ j.1523-1739.2009.01201.x

Dunning, N., T. Beach, and D. Rue. 1997. The paleoecology and ancient settlement of the Petexbatun Region, Guatemala. Ancient Mesoamerica 8:255-266. http://dx.doi.org/10.1017/S0956536100001711

Gavin, M. C., J. McCarter, A. Mead, F. Berkes, J. R. Stepp, D. Peterson, and R. Tang. 2015. Defining biocultural approaches to conservation. Trends in Ecology \& Evolution 30:140-145. http:// dx.doi.org/10.1016/j.tree.2014.12.005

Grossman, Z. 2010. The native renaissance of Washington's tribal nations. American Association of Geographers Newsletter 45:1-11.

Healy, P. F. 2007. The anthropology of Mesoamerican caves. Reviews in Anthropology 36:245-278. http://dx.doi. org/10.1080/00938150701436636

Hernández-Terrones, L., M. Rebolledo-Vieyra, M. MerinoIbarra, M. Soto, A. Le-Cossec, and E. Monroy-Ríos. 2011. Groundwater pollution in a karstic region (NE Yucatan): baseline nutrient content and flux to coastal ecosystems. Water, Air, \& Soil Pollution 218:517-528. http://dx.doi.org/10.1007/s11270-010-0664$\underline{\mathrm{X}}$

Hildebrand, A. R., G. T. Penfield, D. A. Kring, M. Pilkington, A. Camargo, S. B. Jacobsen, and W. V. Boyton. 1991. Chicxulub Crater: a possible cretaceous/tertiary boundary impact crater on the Yucatan Peninsula, Mexico. Geology 19:867-871. http://dx. doi.org/10.1130/0091-7613(1991)019<0867:CCAPCT>2.3.CO;2

Huntington, E. 1912. The peninsula of Yucatan. Bulletin of the American Geographical Society 44:801-822. http://dx.doi. $\underline{\text { org/10.2307/199590 }}$

Instituto Nacional de Estadística y Geografía (INEGI). 2012. Censo General de Poblacion y Vivienda. Instituto Nacional de Estadística y Geografía, Aguascalientes, Mexico. [online] URL: http://www.beta.inegi.org.mx/app/areasgeograficas/?ag=31
Johnson, J. T., R. Howitt, G. Cajete, F. Berkes, R. P. Louis, and A. Kliskey. 2016. Weaving indigenous and sustainability sciences to diversify our methods. Sustainability Science 11:1-11. http:// dx.doi.org/10.1007/s11625-015-0349-X

Jones, G. A., and P. M. Ward. 1998. Privatizing the commons: reforming the ejido and urban development in Mexico. International Journal of Urban and Regional Research 22(1):76-93. http://dx.doi.org/10.1111/1468-2427.00124

Lopez-Maldonado, Y. 2015. Groundwater common pool resources in Yucatan, Mexico: understanding commonisation processes - and anticipating decommonisation - in the cenotes of the Mayan area. Proceedings of the 15th Biennial Conference of the International Association for the Study of the Commons. Edmonton, Alberta, Canada.

Lopez-Maldonado, Y., E. Batllori-Sampedro, C. R. Binder, and B. Fath. 2017. The local groundwater balance model: stakeholders' efforts to address groundwater monitoring and literacy. Hydrological Sciences Journal 1-16. http://dx.doi. org/10.1080/02626667.2017.1372857

Lucero, L. J. 1999. Water control and Maya politics in the southern Maya Lowlands. Archeological Papers of the American Anthropological Association 9:35-49. http://dx.doi.org/10.1525/ ap3a.1999.9.1.35

Lucero, L., J. Gunn, and V. Scarborough. 2011. Climate change and Classic Maya water management. Water 3:479-494. http:// dx.doi.org/10.3390/w3020479

MacLeod, B., and D. E. Puleston. 1978. Pathways into darkness: the search for the road to Xibalba. Proceedings of the Tercera Mesa Redonda de Palenque, M. Greene Robertson and D. Call Jeffers, editors. Palenque, Mexico.

Maffi, L., and E. Woodley. 2010. Biocultural diversity conservation: a global sourcebook. Earthscan, London, UK.

Medina-Elizalde, M., and E. J. Rohling. 2012. Collapse of Classic Maya civilization related to modest reduction in precipitation. Science 335:956-959. http://dx.doi.org/10.1126/science.1216629

Metcalfe, C. D., P. A. Beddows, G. Gold Bouchot, T. L. Metcalfe, H. Li, and H. Van Lavieren. 2011. Contaminants in the coastal karst aquifer system along the Caribbean coast of the Yucatan Peninsula, Mexico. Environmental Pollution 159:991-997. http:// dx.doi.org/10.1016/j.envpol.2010.11.031

Metcalfe, K., R. Ffrench-Constant, and I. Gordon. 2010. Sacred sites as hotspots for biodiversity: the Three Sisters Cave complex in coastal Kenya. Oryx 44:118-123. http://dx.doi.org/10.1017/ $\underline{\text { S0030605309990731 }}$

Myerhoff, B. 1974. Peyote hunt. The sacred journey of the Huichol Indians. Cornell University Press, Ithaca, New York, USA.

Nayak, P. K., and F. Berkes. 2011. Commonisation and decommonisation: Understanding the processes of change in the Chilika Lagoon, India. Conservation and Society 9:132-145. http://dx.doi.org/10.4103/0972-4923.83723

Neurath, J. 2003. Huicholes. Pueblos indígenas del Mexico contemporáneo. Comisión Nacional para el Desarrollo de los Pueblos Indígenas. Programa de las Naciones Unidas para el Desarrollo. Mexico, D.F. 
Nyborg, K., J. M. Anderies, A. Dannenberg, T. Lindahl, C. Schill, M. Schluter, W. N. Adger, K. J. Arrow, S. Barrett, S. Carpenter, F. S. Chapin, A.-S. Crepin, G. Daily, P. Ehrlich, C. Folke, W. Jager, N. Kautsky, S. A. Levin, O. J. Madsen, S. Polasky, M. Scheffer, B. Walker, E. U. Weber, J. Wilen, A. Xepapadeas, and A. de Zeeuw. 2016. Social norms as solutions. Science 354:42-43. http://dx.doi. org/10.1126/science.aaf8317

Ostrom, E. 1990. Governing the commons: The evolution of institutions for collective action. Cambridge University Press, Cambridge, UK. http://dx.doi.org/10.1017/CBO9780511807763

Ostrom, E., J. Burger, C. B. Field, R. B. Norgaard, and D. Policansky, D. 1999. Revisiting the commons: local lessons, global challenges. Science 284:278-282. http://dx.doi.org/10.1126/ science. 284.5412 .278

Oswald-Spring, Ú., and I. Sanchez-Cohen. 2011. Water resources in Mexico: a conceptual introduction. Pages 3-17 in U. OswaldSpring, editor. Water resources in Mexico. Scarcity, degradation, stress, conflicts, management, and policy. Springer, Heidelberg, Germany. http://dx.doi.org/10.1007/978-3-642-05432-7

Oviedo, G., and S. Jeanrenaud. 2007. Protecting sacred natural sites of indigenous and traditional peoples. Pages 77-99 in J. Mallarach, and T. Papayannis, editors. Protected areas and spirituality. Proceedings of the First Workshop of the Delos Initiative, Montserrat 2006. IUCN, and Publicacions de l'Abadia de Montserrat, Gland, Switzerland, and Montserrat, Spain.

Pacheco-Ávila, J., L. Calderón-Rocher, and A. Cabrera-Sansores. 2014. Delineación de la zona de protección hidrogeológica para el campo de pozos de la planta Mérida I, en la ciudad de Mérida, Yucatán, México. Ingeniería 8(1):7-16.

Polanco-Rodríguez, A. G., J. A. Navarro Alberto, J. Solorio Sánchez, G. J. Mena-Rejón, J. Marrufo-Gómez, and T. A. Del Valls Casillas. 2015. Contamination by organochlorine pesticides in the aquifer of the Ring of Cenotes in Yucatán, México. Water and Environment Journal 29:140-150. http://dx.doi.org/10.1111/ wej. 12080

Prufer, K. M., and P. S. Dunham. 2009. A shaman's burial from an Early Classic cave in the Maya Mountains of Belize, Central America. World Archaeology 41:295-320. http://dx.doi. org/10.1080/00438240902844236

Samakov, A., and F. Berkes. 2016. Ysyk-Köl Lake, the Planet's third eye: sacred sites in Ysyk-Köl Biosphere Reserve. Pages 208-220 in B. Verschuuren and N. Furuta, editors. Asian sacred natural sites, philosophy and practice in protected areas and conservation. Routledge, London, UK.

Scarborough, V. L. 1998. Ecology and ritual: water management and the Maya. Latin American Antiquity 9:135-159. http://dx.doi. org/10.2307/971991

Scarborough, V. L., and G. G. Gallopin. 1991. A water storage adaptation in the Maya Lowlands. Science 251:658-662. http:// dx.doi.org/10.1126/science.251.4994.658

Secretaría de Desarrollo Urbano y Medio Ambiente (SEDUMA). 2014. Cave survey of Yucatan, Merida, Mexico. SEDUMA, Mérida, Mexico. [online] URL: http://www.seduma. yucatan.gob.mx/cenotes-grutas/censo-cenotes.php
Thorley, A., and C. M. Gunn. 2008. Sacred sites: an overview. A report for the Gaia Foundation. The Gaia Foundation, London, UK.

Torres-Mazuera, G. 2009. La territorialidad rural Mexicana en un contexto de descentralización y competencia electoral. Universidad Nacional Autónoma de Mexico, Instituto de Investigaciones Sociales. Revista Mexicana de Sociología 71 (3):453-490.

Turner, B. L., and J. A. Sabloff. 2012. Classic Period collapse of the Central Maya Lowlands: insights about human-environment relationships for sustainability. Proceedings of the National Academy of Sciences of the United States of America 109:13908-13914. http://dx.doi.org/10.1073/pnas.1210106109

Universidad Nacional Autonoma de Mexico (UNAM). 2015. Descubren universitarios un cenote debajo de la pirámide de Kukulkán, en Chichén Itzá. Boletín UNAM-DGCS. 466.

Veni, G. 1990. Maya utilization of karst groundwater resources. Environmental Geology and Water Sciences 16:63-66. http://dx. doi.org/10.1007/BF01702224

Verschuuren, B., and N. Furuta, editors. 2016. Asian sacred natural sites. Philosophy and practice in protected areas and conservation. Routledge, London, UK.

Western, D., and M. Wright. 1994. Natural connections: perspectives in community-based conservation. Island Press, Washington, D.C., USA.

Wild, R., and C. McLeod, editors. 2008. Sacred natural sites: guidelines for protected area managers. IUCN, Gland, Switzerland.

Yin, R. K. 2009. Case study research. Design and methods. Fourth edition. Sage, Thousand Oaks, California.

Zurba, M., and F. Berkes. 2014. Caring for country through participatory art: creating a boundary object for communicating indigenous knowledge and values. Local Environment 19:821-836. http://dx.doi.org/10.1080/13549839.2013.792051 